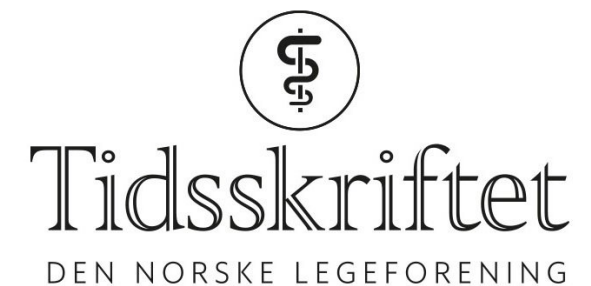

DEN NORSKE LEGEFORENING

\title{
Undervisning har lav status innen akademia
}

DEBATT

\section{ELISABETH GULOWSEN CELIUS}

E-post: uxelgu@ous-hf.no

Elisabeth Gulowsen Celius er spesialist i nevrologi, overlege ved Nevrologisk avdeling, Oslo universitetssykehus og professor ved Institutt for helse og samfunn.

Forfatter har fylt ut ICMJE-skjemaet og oppgir å ha mottatt honorar fra Almirall, Biogen, Novartis, Teva, Sanofi, Roche og Merck og forskningsstøtte fra Novartis og Sanofi.

Undervisningens anseelse må styrkes. Det må etableres et system som gjør at god undervisning gir meritter ved vurdering av akademisk kompetanse.

En doktorgrad betyr at man er kvalifisert til å undervise, og er en forutsetning for å kvalifisere seg til en akademisk stilling. I vurderingen skal både forskning, ledelse og undervisning vektlegges. Erfaringsmessig veier forskningen tyngst.

Arbeidsoppgavene i en akademisk hovedstilling omfatter undervisning, ledelse og forskning; ansatte i bistillinger har andre oppgaver i tillegg. I dag evalueres undervisningen kvantitativt, mens forskningen evalueres både ut fra kvantitet (antall publikasjoner) og kvalitet (impact factor). Det finnes ikke noe formalisert system for evaluering av ledelse. I hverdagen har forskning høy anseelse, mens evnen til å undervise sjelden vektlegges.

\section{Hva er målet med undervisningen?}

Målsettingen med all undervisning er å overbringe kunnskap. Endringer i samfunnet og i tilgang til informasjon har også medført endringer i undervisningen. I dag er det mulig å hente mye kunnskap blant annet på internett. Oppgaven for den som underviser, blir derfor i stor grad å veilede studentene i innhenting og tolkning av informasjonen.

Nasjonalt organ for kvalitet i utdanning (NOKUT) og Nasjonalt kvalifikasjonsrammeverk for livslang læring arbeider med utdanningsledelse, læringsledelse og digitalt lederskap i høyere utdanning (1). Det stilles krav om måloppnåelse, emneplaner, læringsutbytte, digitalisering og aktivisering av studenter. Samtidig er det behov for å utvikle metoder for evaluering av ulike undervisningsformer og læringsutbytte.

\section{Hvordan undervise i dag?}

Studier viser at norske studenter bruker mindre tid på studiene enn studenter i andre europeiske land, og de arbeider mest ved siden av studiene (2). Det varierer i hvilken grad de leser tradisjonelle lærebøker, men de benytter ofte PowerPoint-presentasjoner fra forelesninger til gjennomgang av pensum (1). Selv om dagens studenter er vokst opp med 
digitale medier, printer flertallet ut viktige artikler og leser dem på papir. Den digitale kompetansen hos universitetslærerne er variabel, og bruk av digitale plattformer i undervisning og i kontakt med studentene er foreløpig begrenset. Hovedtyngden av undervisningen er tradisjonelle forelesninger og seminarer. Mye tyder på at studentenes utbytte øker hvis de har lest pensum på forhånd, aktiviseres i undervisningssituasjonen og har anledning til å bearbeide stoffet etterpå (1).

Hvordan skal man legge opp undervisningen slik at studentene lærer mest mulig? Digitale løsninger har en plass, men bør være gjennomtenkte. Evne til å komme i dialog med studentene synes å være en nøkkel til å lykkes (3). Bruk av responsteknologi (f.eks. kahoot, mentimeter) i undervisningen er studentaktiviserende og øker læringsutbyttet (4). Samtidig har man sett at bruk av «speilvendt» undervisning (flipped classroom) krever at studentene forbereder seg for å ha utbytte (1).

Ulikheter mellom undervisere og studenter når det gjelder sosiale, sosioøkonomiske, språklige og kulturelle forhold kan være en utfordring. Økende internasjonalisering gjør at studentene har en mer variert bakgrunn, og kravene til dialog øker (5).

\section{Hvordan utdanne gode undervisere?}

Det obligatoriske kurset i universitetspedagogikk er svært nyttig. Et kritisk blikk på egen undervisning kan heve kvaliteten. Kursets tverrfakultære karakter er en nøkkel til kursets suksess. Kolleger fra andre fagområder har lettere for å evaluere selve undervisningen, mens kolleger fra eget fagområde uvilkårlig fester seg mer ved det faglige. Oppfriskningskurs eller krav til en «fagdag» om undervisning med jevne mellomrom kunne bidratt til å opprettholde oppmerksomheten på undervisning.

I de senere år har emnet for prøveforelesningen ved en doktorgradsprøve blitt lagt tett opp til avhandlingen (6). Dermed testes ikke ph.d.-kandidatenes evne til å sette seg inn i et nytt emne og lage en ny forelesning, slik intensjonene med prøveforelesningen er. Tidligere måtte kandidaten holde to forelesninger om både et selvvalgt og et oppgitt emne. Reduserte krav kan ses som et bidrag til nedvurderingen av undervisningens plass på universitetene.

\section{Hvordan evaluere undervisning?}

Hvordan skal man evaluerer kvaliteten på undervisningen? Skal man basere seg på rekruttering, karakterer, gjennomstrømning, studentevalueringer, fagfellevurdering eller egenevaluering? Siden evnen til kritisk å vurdere sin egen prestasjon vil variere fra person til person, er egenevaluering sannsynligvis ikke veien å gå.

Det finnes ulike skjemaer for fagfelleevaluering av undervisning. Universitetene bør utvikle et felles, strukturert skjema. Studentenes evne til evaluering er omdiskutert, og det velkjente eksperimentet «Dr. Fox-effekten» viste at stort engasjement hos en underviser kan forlede studenter til å tro på oppspinn (7). Det finnes ikke studier som sammenligner studentenes evaluering av undervisningen med undervisers egenevaluering og fagfelleevaluering.

\section{Hva kan man gjøre?}

Undervisningens anseelse på universitetene må styrkes, og undervisningen må gi meritt. Prøveforelesningene må teste evnen til å lage en ny forelesning. Ved ansettelse i akademisk stilling må undervisningserfaring vektlegges. Studentene må digitalt evaluere en viss andel av undervisningen for å gå opp til eksamen. Samtidig bør det innføres fagfellevurdering av 1-2 forelesninger gjennom en 5-årsperiode for å kunne bibeholde en akademisk stilling, tilsvarende kravet til forskningspublisering. Etter modell av kursene i universitetspedagogikk bør evalueringene gjøres tverrfakultært og knyttes til en obligatorisk fagdag i universitetspedagogikk. 
LITTERATUR:

1. Krumsvik RJ, Jones Lø. Utdanningsledelse og digitale læringsformer i høyere utdanning. Uniped 2017; 40: 18 - 37. [CrossRef]

2. Einarsen K. Norske studenter bruker minst tid på studiene. Samfunnsspeilet 2014; nr. 4:15-20.

3. Vygotsky LS. Mind in society. Cambridge, MA: Harvard University Press, 1978.

4. Smith MK, Wood WB, Adams WK et al. Why peer discussion improves student performance on inclass concept questions. Science 2009;323: 122 - 4. [PubMed][CrossRef]

5. Nordgren M. Mangfold, dialog og læring. Norske pedagogisk tidsskrift 2016; 100: 49 - 6o. [CrossRef]

6. Gjersvik P. Prøveforelesningens hensikt undergraves - fortsatt. Tidsskr Nor Legeforen 2017; 137: doi: 10.4045/tidsskr.17.0837. [PubMed][CrossRef]

7. Strømsø H. Forførende entusiasme: 40-års forskning på Dr. Fox effekten. Uniped 2016; 39: 118 - 30.

Publisert: 21. august 2018. Tidsskr Nor Legeforen. DOI: 10.4045/tidsskr.18.0341

Mottatt 19.4.2018, første revisjon innsendt 12.6.2018, godkjent 25.6.2018.

(C) Tidsskrift for Den norske legeforening 2020. Lastet ned fra tidsskriftet.no 